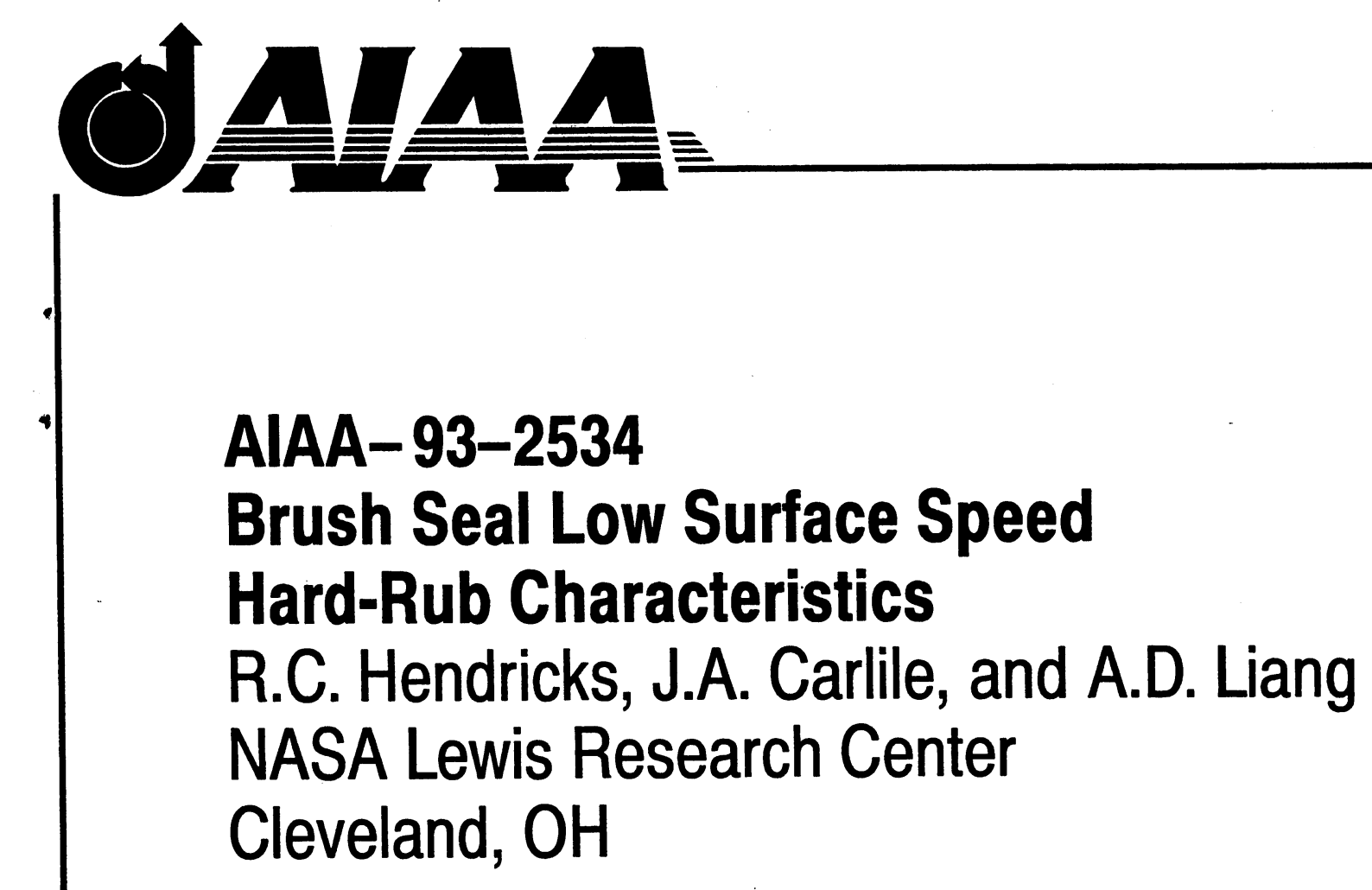

AIAA/SAE/ASME/ASEE 29th Joint Propulsion Conference and Exhibit June 28-30, 1993 / Monterey, CA 
NASA Technical Memorandum 106169

AIAA-93-2534

\section{Brush Seal Low Surface Speed Hard-Rub Characteristics}

Robert C. Hendricks, Julie A. Carlile, and Anita D. Liang Lewis Research Center

Cleveland, Ohio

Prepared for the

29th AIAA Joint Propulsion Conference and Exhibit cosponsored by the AIAA, SAE, ASME, and ASEE

Monterey, California, June 28-30, 1993 


\title{
BRUSH SEAL LOW SURFACE SPEED HARD-RUB CHARACTERISTICS
}

\author{
Robert C. Hendricks, Julie A. Carlile, and Anita D. Liang \\ National Aeronautics and Space Administration \\ Lewis Research Center \\ Cleveland, Ohio 44135
}

\section{Abstract}

The bristles of a 38.1-mm (1.5-in.) diameter brush seal were flexed by a tapered, 40-tooth rotor operating at $2600 \mathrm{rpm}$ that provided sharp leading-edge impact of the bristles with hard rubbing of the rotor lands. Three separate tests were run with the same brush accumulating over $1.3 \times 10^{9}$ flexure cycles while deteriorating $0.2 \mathrm{~mm}$ (0.008 in.) radially. In each, the test bristle incursion depth varied from 0.130 to $0.025 \mathrm{~mm}(0.005$ to $0.001 \mathrm{in}$.) or less (start to stop), and in the third test the rotor was set $0.25 \mathrm{~mm}(0.010 \mathrm{in}$.) eccentric. Runout varied from 0.025 to $0.076 \mathrm{~mm}(0.001$ to $0.003 \mathrm{in}$.) radially. The bristles wore but did not pull out, fracture, or fragment. Bristle and rotor wear debris were deposited as very fine, nearly amorphous, highly porous materials at the rotor groove leading edges and within the rotor grooves. The land leading edges showed irregular wear and the beginning of a convergent groove that exhibited sharp, detailed wear at the land trailing edges. Surface grooving, burnishing, "whipping," and hot spots and streaks were found. With a smooth-plug rotor, post-test leakage increased 30 percent over pretest leakage.

\section{Introduction}

High-performance, lightweight engines require compliant seal configurations to accommodate flexible interfaces. Thus, in many aircraft gas turbine engines and other turbomachines brush seal systems are being proposed to replace labyrinth seals because brush seals are compliant and reliable, leak less, cost less, and enhance rotor stability. Brush seals have been the subject of much recent seals research. ${ }^{1-20}$

A typical brush seal configuration (Fig. 1) (courtesy of Cross Mfg. Ltd. ${ }^{1}$ ) consists of (1) a backing plate (like a sealing dam), (2) a circumferential or linear set of packed wires (fibers or bristles), (3) a pinch plate that serves as a retainer for the brush bristles, and (4) an outside diameter surface that fits tightly to the housing (insert in Fig. 1). The flexibility of the fibers and implicitly the performance of this seal are governed by many factors as expressed in terms of similitude parameters. ${ }^{9,20}$ Among these factors are fiber length and diameter, inclination to the moving surface, surface speed, interface friction, seal diameter, fluid properties, packing density, modulus of elasticity, backing plate clearance, and preload or interference fit.

Typically for a circular brush, the wire or brush materials are superalloys and range from 0.05 to $0.07 \mathrm{~mm}(0.002$ to $0.0028 \mathrm{in}$.) in diameter. The bristles are approximately $0.96 \mathrm{~mm}(0.38 \mathrm{in}$.) long and are aligned at $30^{\circ}$ to $50^{\circ}$ to the shaft in the direction of rotation. Nominally, there are 98 bristles/mm (2500 bristles/in.) of circumference. The interface is characterized by a smooth ( 4 to $20 \mathrm{rms}$ ), hardened rub surface on the shaft (e.g., $\mathrm{Al}_{2} \mathrm{O}_{3}$ or for short duration the uncoated shaft itself). Because brush seals are contact seals with radial interferences ranging from zero to more than $0.25 \mathrm{~mm}(0.01 \mathrm{in}$.), ceramic coatings and superalloy materials are often used to enhance life and minimize wear at elevated surface speeds, temperatures, and pressure drops.

Although brush seals show promise for future applications, it must be acknowledged that brush seals are most effective as contact seals and that life and wear rates are major concerns. Whereas bristle blowout will cause excessive leakage, bristle loss and debris have a potential for destructive impact on the powerplant. Thus, the issues of bristle pullout, surface rubbing, bristle wear, and debris are qualitatively addressed in this paper.

The authors are aware that other data exist for ranges of interference fits and other configurations, but the results are proprietary.

\section{Apparatus}

The "drill press" apparatus was similar to that described in Ref. 2. In the tests of Ref. 2 the 38.1-mm (1.5-in.) diameter brush seal was fixed in a pressure vessel and the rotor was a smooth-surface, tapered plug turning at $400 \mathrm{rpm}$. Leakage data at various interferences and eccentricities have been reported. ${ }^{19}$

In the tests described herein the 38.1-mm (1.5-in.) diameter brush seal was again mounted in the pressure vessel that simulated the static housing; but for these tests flutes were machined the length of the plug rotor, providing a set of 40 lands and 40 grooves, or a 40 -tooth rotor (Fig. 2). The lands were $1.638 \pm 0.04 \mathrm{~mm}$ 
$(0.0645 \pm 0.0015 \mathrm{in}$.) just above the groove at test 3 and $1.582 \pm 0.04 \mathrm{~mm}(0.0623 \pm 0.0015 \mathrm{in}$.) just below the groove at test 1; see rotor sketch on Table II. The groove width averaged 1.397 to $1.422 \mathrm{~mm}(0.055$ to 0.056 in.) with further dimensions provided in Tables I and II. Prior to testing the machining tool marks were clear, being axial in the grooves and circumferential on the lands. This rotor provided 40 impacts of the brush bristles per revolution and was rotated at $2600 \mathrm{rpm}$.

The 38.1-mm (1.5-in.) diameter brush seal (Fig. 3) was damaged in a previous series of tests related to Ref. 2. The damaged section, although quite small and having a "chewed" appearance, increased seal leakage. The seal could no longer be used for leakage tests but was adequate for the tests herein.

The rotor was AISI 304 stainless steel, and the brush bristles were Haynes 25 in the annealed condition. When stainless steel is rubbed during a machining operation, it tends to change from a "gummy" machining material to a surface-work-hardened material. As a result the bristles would be expected to rub-machine the stainless steel, and in turn the stainless steel would be expected to abrasively remove the bristles.

In test 1 the interference was set at 0.025 to $0.050 \mathrm{~mm}(0.001$ to $0.002 \mathrm{in}$.) with the groove depth at 0.05 to $0.08 \mathrm{~mm}$ ( 0.002 to $0.003 \mathrm{in}$.). As expected the bristles rub-machined the rotor.

For test 2 the plug rotor was reset to a portion of the surface that was unrubbed. At that point the groove depth was 0.08 to $0.13 \mathrm{~mm}(0.003$ to $0.005 \mathrm{in}$.). The interference fit between the rotor lands and the brush was 0.05 to $0.08 \mathrm{~mm}$ (0.002 to $0.003 \mathrm{in}$.).

For test 3 the plug rotor was again reset to a portion of the surface that was unrubbed. The groove depth was 0.178 to $0.254 \mathrm{~mm}$ ( 0.007 to $0.010 \mathrm{in}$.). For this test the rotor was initially set $0.33 \mathrm{~mm}(0.013 \mathrm{in}$.) eccentric, but the rotor rubbed the fence (backing washer) slightly. The fence diameter was $39.2 \mathrm{~mm}$ $(1.544$ in.). The rotor was then reset to an estimated static eccentricity less than $0.25 \mathrm{~mm}$ ( $<0.010 \mathrm{in}$.). The dynamic eccentricity was estimated to be less than $1 \mathrm{~mm}(<0.004 \mathrm{in}$.). No active clearance measurements were made during these tests; these estimates of eccentricities were made from post-test photographs and static measurements. These settings provided a test with significant rotor impacting and incursion at one portion of the seal and no rubbing contact diametrically opposite to that position.

In tests 1 and 2 the smooth rotor and the 40-tooth rotor were assumed to be interchangeable. The repositioning of the stator for test 3 introduced an unaccountable bias that was estimated in order to correlate the measured flow rates. For test 3 the smoothrotor initial static eccentricity was estimated to be less than $0.15 \mathrm{~mm} \quad(<0.006 \mathrm{in}$.), and after test 3 the estimated static eccentricity was less than $0.25 \mathrm{~mm}$ $(<0.010$ in.).

\section{Results}

The results are separated into observations of (1) the brush bristle flexure cycles with associated interface damage to the brush seal and the rotor and (2) the leakage or performance changes.

\section{Bristle Flexure and Interface Damage}

Visualization of the rotor-brush interface at creeping surface speeds (under $10 \mathrm{rpm}$ ) revealed little groove penetration. In the impact zone the brush stiffness and the low void did not permit a fully deflected or extended set of bristles at the interface. Instead the impact compacted the bristles in the circumferential direction into the brush and spread the bristles in the axial direction at the rate of 40 times per revolution.

Time of testing and brush diameters before and after testing for the three tests are presented in Table I; additional dimensions are given in Table $I$. The diameters were obtained by inspecting the brush on an optical comparator before and after each test. The chewed area and a few stray wires served as reference positions for measurements.

Optical inspection of the grooves cut by the brush into the stainless steel rotor (test 1 ) showed that the cut converged from the leading edge to the trailing edge of the land as the wires (bristles) crossed the rotor (Fig. 4). Wire grooves were clear cut and debris was evident, as is better shown in the enlargement (Fig. 5).

The following groove extents in millimeters (inches) were measured in test 1:

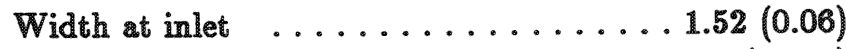

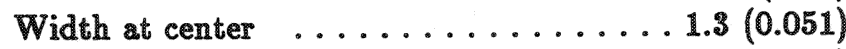

Width at outlet $\ldots \ldots \ldots \ldots \ldots \ldots \ldots .27(0.05)$

For test 2 the inlet region at the land leading edge was extensive and not readily characterized, but a general convergence pattern was evident. Similar behavior at the leading edge was noted for test 3.

In order to corroborate the optical results, profilometer results for a typical tooth of the 40-tooth rotor were taken. Wear area and groove depth estimates are 
provided in Table III. Values for the extent of the groove in millimeters (inches) are shown in Figs. 6 to 8 at a resolution of $0.02 \mathrm{~mm} /$ division.

Width within $0.1 \mathrm{~mm}$ of inlet $\ldots \ldots \quad 0.9(0.035)$

Width at center $\ldots \ldots \ldots \ldots \ldots \ldots 0.4(0.016)$

Width within $0.08 \mathrm{~mm}$ of outlet $\ldots . .0 .27(0.011)$

It is evident that the optical values for groove extent were much larger than those from the profilometer. The problem is the scale used in defining the groove depth. For example, at a resolution of $0.01 \mathrm{~mm} /$ division the width at the center is $1.15 \mathrm{~mm}(0.045 \mathrm{in}$.), but at a resolution of $0.02 \mathrm{~mm} /$ division the width at the center is $0.4 \mathrm{~mm}$ (0.016 in.). At the smaller resolution the extent of the scratched interface generally agrees with the optical values, but at the larger resolution the extent of the scratched interface is not resolved (i.e., detail is lost).

For the surface asperity resolution used herein the optical method better defined the extent (width) of the damaged interface; the profilometer provided the depth. At one-half the depth resolution only the major grooving was defined.

The first profile, labeled "leading edge," was taken within $0.10 \mathrm{~mm}(0.004 \mathrm{in}$.) of the leading edge and shows a broad damage region with deep grooving for test 2 (Fig. $7(\mathrm{a})$ ) and test 3 (Fig. 8(a)) but a minor amount of material damage for test 1 (Fig. 6(a)). The material buildup adjacent to the groove of test 3 probably occurred during rotor-fence rub. The second profile, labeled "mid section," was taken midway between the tooth leading and trailing edges. The damage of test 2 (Fig. $7($ b)) and test 3 (Fig. 8(b)) was severe, and a twofold cut has developed in the rotor during test 2. Again moderate damage was noted for test 1 (Fig. 6(b)). The third profile, labeled "trailing edge," was taken within 5 percent of the trailing edge. The grooving seen in the midsection profile carried through with perhaps some sharpness of the features near the trailing edge (Figs. $6(\mathrm{c}), 7(\mathrm{c})$, and $8(\mathrm{c})$ for tests 1,2 , and 3 , respectively).

The trailing edge of the land was "cut" clean by the brush in all three tests in stark contrast to the erratic leading-edge surface, which was whipped by the bristles. Of interest is the contrast between the land surface cuts. Test 1 surface cuts were a simple wear scar; those of tests 2 and 3 were multiple grooves with complex surfaces and burnishing. The most rotor damage appeared from test 2 and the most brush damage from test 3 , where the rotor was set eccentric.

The brush bristle impact at the leading edge left material deposits that were magnetic (i.e., from the rotor) and rust color (probably $\mathrm{Fe}_{3} \mathrm{O}_{4}$ ) with a spongelike (or cauliflower) appearance (Fig. 9); these deposits are readily seen at higher magnification $(80 \mathrm{X})$ in Fig. 10. Debris was generated by surface machining grooves, "whipping" of the leading edge, burnishing, and sharp trailing edges. The deposited materials were fine, porous, "greasy" to the fingers, and readily removed from the rotor; removal from the bristles was not straightforward. Standard degreasing cleaned but not thoroughly, and ultrasonic cleaning was not attempted. The reasoning was to see if these deposits would inhibit the responsive character of the bristles. The debris can affect both the response and the leakage, but neither effect was observed in these tests. Further work here is warranted.

These deposits also indicate rapid wear-in with a long oxidation period for the "machined out" material. The materials deposited on the groove wall at the land leading edge (Fig. 10) and on the groove wall at the land trailing edge (Fig. 11) had little or no structure; the defraction spectra were peakless.

It is speculated that the bristles were dragged across the land, with "machined" material adhering to the bristle and then "impacted" off the bristle at the leading edge of the next tooth. Some of the materials were deposited within the groove. Black nodule-like debris tended to adhere to the groove wall at the land trailing edge. This black material and rust-colored materials formed in the groove at the land leading edge.

Stainless steel work hardens so that the cut grooves were probably harder than the parent stainless steel and would wear the annealed Haynes 25 bristles. The smooth grooves, the hot spots, and the hot streaking may indicate that a thin layer of stainless steel flowed plastically as it was machined out. Because of the incursive impact of the toothed rotor and the heated interface, the Haynes 25 bristles could lose strength, erode, fracture, or pull out as massive debris. But no pullouts or massive debris was found after any of the three tests. At higher magnification (200X) the tips still appear intact without fracture, but wear is evident and oxidation debris appears to be well adhered to the surface (Fig. 12). As further evidence of the bristle wear an examination of the bristle tip surface revealed tip grooving, and the severe impacting on the bristles is shown by erratic wear notches on the bristle surface.

These tests, although preliminary and only qualitative, begin to mitigate the fear of brush seal disintegration through bristle flexing as over $1 \times 10^{9}$ cycles were sustained without failure, fracture, or pullout. However, the required flexures for flight operations are at least an order of magnitude higher with parameters such as surface speed, temperature, pressure, and materials to be considered. 
Bristle flexures raise an equally troubling concern over seal life, because brush seals do wear out. Once these seals begin to reach line-to-line contact, their leakage can be equivalent to that of an advanced labyrinth seal. The sealing margin and competitive edge of the worn brush seal begin to fade. New competitive (lower leakage) configurations for labyrinth, damper, honeycomb, feltmetal, and spiral-groove seals are under investigation. It is clear that long-duration component and engine testing at elevated surface speeds and working fluid temperatures are required.

\section{Correlation of Leakage Data}

Although not the primary objective of this experiment, overall changes in brush leakage were estimated from flow checks before and after testing. In order to determine these leakages the 40-tooth rotor was replaced with a smooth-surface, tapered rotor. Runout errors resulting from rotor interchange were unresolved as were those associated with the static eccentricity of test 3 . Measurements characterizing the rotor and brush before and after testing are given in Table I. The average depth of the brush-cut groove as well as the estimated clearances are given in Tables II and III.

Leakage is characterized in Fig. 13 in terms of volumetric flow rate as a function of pressure drop across the brush seal before and after each of the three tests. Both pretest and post-test results are provided in the same figure. Because this brush seal was damaged (see Apparatus section), absolute leakage measurements would require weighing, but the relative leakage should be accurate. The interference fits for the brush seal leakage data for pretests 1 and 2 were nearly the same, resulting in corresponding leakages. While taking data it was found that the brush would stiffen and the pressure drops would increase. Data points illustrating hystersis (typical in brush seals) are shown. After correcting the post-test 2 data for clearance, these test results agreed with those of post-test 1.

Setting the rotor eccentric in test 3 proved a major problem in cross correlating the leakage results. The estimated initial static eccentricity for the smooth rotor was less than $0.15 \mathrm{~mm}$ (0.006 in.), and the smooth rotor and the 40-tooth rotor were assumed to be interchangeable at the same spindle loading. However, the rotor rubbed the fence (backing washer) slightly, requiring an initial static eccentricity of $0.36 \mathrm{~mm}(0.014 \mathrm{in}$.) and implying a difference in spindle loading. The rotor was reset to an estimated eccentricity of less than $0.025 \mathrm{~mm}$ (0.010 in.). Post-test examination indicated that the dynamic eccentricity was $<0.10 \mathrm{~mm}(<0.004 \mathrm{in}$.).
From the data of Ref. 19 a relation was found for the change in pressure as a function of eccentricity at a fixed volumetric flow rate. Using this relation and corrections for clearance and assuming a pretest static eccentricity of $0.15 \mathrm{~mm}(0.006 \mathrm{in}$.) and a post-test static eccentricity of $0.25 \mathrm{~mm}(0.010 \mathrm{in}$.) show that the results of test 3 were overcorrected by 20 percent with respect to the results of tests 1 and 2. Future testing requires instrumentation to overcome these positioning errors. Nevertheless, these leakage data indicate that under conditions of severe brush and rotor wear the brush seal leakage increased 30 percent. And, although brush seal performance degraded, the brush seal did not fail.

\section{Summary of Results}

In three separate tests with a 40-tooth tapered stainless steel rotor operating at $2600 \mathrm{rpm}$ and a 38.1-mm (1.5-in.) diameter brush seal with $0.07-\mathrm{mm}$ (0.0028-in.) diameter annealed Haynes 25 bristles set at a nominal $0.076-\mathrm{mm}(0.003-i n$.) radial interference for each test, the following results were obtained:

1. The bristles withstood over $1 \times 10^{9}$ cycles without pullout, fracture, or massive debris generation.

2. Rotor grooving up to $0.076 \mathrm{~mm}(0.003 \mathrm{in}$ ) in depth radially with erratic "whipped" leading-edge surfaces followed by convergent grooving to a clean-cut trailing edge was commonplace for each of the three tests.

3. Most of the debris generated was a fine black material that appeared amorphous, but the rust-colored materials were iron rich and magnetic, implying $\mathrm{Fe}_{3} \mathrm{O}_{4}$. The debris was "cauliflower" in form and highly porous with low adhesion, except for that which was fine enough to adhere to the bristles. Those fines were not readily dislodged. Nonuniform fines (or oxidation) adhering to the bristles tended to separate the bristles, increasing porosity, and would enhance leakage paths.

4. Radial bristle losses up to $0.2 \mathrm{~mm}$ (0.008 in.) were demonstrated, which if left uncorrected would lead to equivalent or higher leakages than those of labyrinth seals. Bristle loss at elevated surface speeds and temperatures requires further study.

5. Generated debris can impair bristle motion and alter leakage, but within the limitations of this experiment these considerations were not a problem. They remain as issues to be resolved. 
6. Under conditions of severe rotor-stator interface damage, the brush seal leakage performance degraded 30 percent, but the seal did not fail.

\section{References}

1. Ferguson, J.G.: Brushes as High Performance Gas Turbine Seals: ASME Paper 88-GT-182, 1988.

2. Flower, R.: Brush Seal Development Systems. AIAA Paper 90-2143, 1990.

3. Chupp, R.; and Nelson, P.: Evaluation of Brush Seals for Limited Life Gas Turbine Engines. AIAA Paper 90-2140, 1990.

4. Holle, G.; and Krishnan, M.: Gas Turbine Engine Brush Seal Applications. AIA Paper 90-2142, 1990.

5. Conner, K.J.; and Childs, D.W.: Brush Seal Rotordynamic Damping Characteristics. AIAA Paper 90-2139, 1990.

6. Hendricks, R.C., et al.: A Bulk Flow Model of a Brush Seal System. ASME Paper 91-GT-325, 1991.

7. Hendricks, R.C., et al.: Some Preliminary Results of Brush Seal/Rotor Interference Effects on Leakage at Zero and Low RPM Using a Tapered-Plug Rotor. AIAA Paper 91-3390, 1991. (Also NASA TM-104396, 1991.)

8. Chupp, R.; and Dowler, C.: Flow Coefficient for Brush Seals. Presented at the 28th Joint Propulsion Conference, Nashville, TN, July 6-8, 1992.

9. Hendricks, R.C., et al.: Brush Seals in Vehicle Tribology. Presented at the 13th Leeds-Lyon Symposium on Tribology, Leeds, England, 1990.

10. Gorelov, G.M., et al.: An Experimental Study of the Rate Characteristics of Brush Seals in Comparison With Labyrinth Seals. Aviats. Tekh., no. 4, 1988, pp. 43-46.

11. Braun, M.J.; Hendricks, R.C.; and Canacci, V.A.: Non-Intrusive Qualitative and Quantitative Flow Characterization and Bulk Flow Model for Brush
Seals. Proceedings of Japan International Tribology Conference, ASME, New York, 1990, pp. 1611-1616.

12. Braun, M.J.; Hendricks, R.C.; and Canacci, V.A.: Flow Visualization in a Simulated Brush Seal. ASME Paper 90-GT-217, 1990.

13. Braun, M.J.; Hendricks, R.C.; and Canacci, V.A.: Flow Visualization and Quantitative Velocity and Pressure Measurements in Simulated Single and Double Brush Seals. STLE Tribol. Trans., vol. 34, Jan. 1991, pp. 70-80.

14. Braun, M.; Canacei, V.A.; and Hendricks, R.C.: Flow Visualization and Motion Analysis for a Series of Four Sequential Brush Seals. AIAA Paper 90-2482, 1990.

15. Mullen, R.L.; Braun, M.J.; and Hendricks, R.C.: Numerical Modeling of Flows in Simulated Brush Seal Configurations. AIAA Paper 90-2141, 1990.

16. Hendricks, R.C., et al.: Investigation of Flows in Bristle and Fiberglas Brush Seal Configurations. ISROMAC-4: The Fourth International Symposium of Transport Phenomena and Dynamics of Rotating Machinery, Hemisphere Publ., New York, 1992, pp. 315-325.

17. Carlile, J.A.; Hendricks, R.C.; and Yoder, D.A.: Brush Seal Leakage Performance With Gaseous Working Fluids at Static and Low Rotor Speed Conditions. NASA TM-105400, 1992.

18. Braun, M.J.; Hendricks, R.C.; and Yang, Y.: Effects of Brush Seal Morphology on Leakage and Pressure Drops. AIAA Paper 91-2106, 1991.

19. Schlumberger, J.A.; Proctor, M.; and Hendricks, R.C.: Eccentricity Effects on Leakage of a Brush Seal at Low Surface Speeds. NASA TM-105141, 1991.

20. Hendricks, R.C.; Carlile, J.A.; and Liang, A.D.: Some Sealing Concepts - A Review. Part A: Industrial, Proposed and Dynamic; Part B: Brush Seal Systems. ISROMAC-4: The Fourth International Symposium of Transport Phenomena and Dynamics of Rotating Machinery, Hemisphere Publ., New York, 1992, pp. 247-277. 
TABLE I.-DIAMETRAL CHANGES AND TEST CYCLE TIMES FOR

38.1-mm (1.5-in.) DIAMETER BRUSH SEAL

[Seal fence inside diameter, $1.543 \pm 0.0005$ in.]

\begin{tabular}{|c|c|c|c|c|c|}
\hline & \multicolumn{4}{|c|}{ Position } & \multirow[t]{4}{*}{ Average } \\
\hline & Vertical & Horizontal & Vertical & Horizontal & \\
\hline & \multicolumn{4}{|c|}{ Rotation, deg } & \\
\hline & \multicolumn{2}{|c|}{0} & \multicolumn{2}{|c|}{45} & \\
\hline & \multicolumn{5}{|c|}{ Brush diameter (from optical comparator inspection), in. } \\
\hline $\begin{array}{l}\text { Before test } 1 \\
\text { After test } 1^{\mathrm{s}} \\
\end{array}$ & $\begin{array}{l}1.494 \\
1.497 \\
\end{array}$ & $\begin{array}{l}1.4918 \\
1.496 \\
\end{array}$ & $\begin{array}{l}1.4926 \\
1.495 \\
\end{array}$ & $\begin{array}{l}1.4945 \\
1.495 \\
\end{array}$ & $\begin{array}{l}1.4932 \\
1.4958 \\
\end{array}$ \\
\hline Change, in. & 0.003 & 0.0042 & 0.0024 & 0.0005 & 0.00255 \\
\hline $\begin{array}{l}\text { Before test } 2 \\
\text { After test } 2^{b}\end{array}$ & $\begin{array}{l}1.495 \\
1.5058 \\
\end{array}$ & $\begin{array}{l}1.495 \\
1.5061 \\
\end{array}$ & $\begin{array}{l}1.497 \\
1.5011 \\
\end{array}$ & $\begin{array}{l}1.496 \\
1.5037 \\
\end{array}$ & $\begin{array}{l}1.4958 \\
1.5049 \\
\end{array}$ \\
\hline Change, in. & 0.0108 & 0.0111 & 0.0071 & 0.0077 & 0.00918 \\
\hline $\begin{array}{l}\text { Before test } 3 \\
\text { After test } 3^{c}\end{array}$ & $\begin{array}{l}1.5058 \\
1.504\end{array}$ & $\begin{array}{l}1.5061 \\
1.514 \\
\end{array}$ & $\begin{array}{l}1.5041 \\
1.512 \\
\end{array}$ & $\begin{array}{l}1.5037 \\
1.5064 \\
\end{array}$ & $\begin{array}{l}1.5049 \\
1.5091 \\
\end{array}$ \\
\hline Change, in. & -0.0018 & 0.0079 & 0.0079 & 0.0027 & 0.00418 \\
\hline
\end{tabular}

Total test time, $70.3 \mathrm{hr}$.

botal test time, $43 \mathrm{hr}$.

'Total test time, $109 \mathrm{hr}$. 
TABLE II.-ADDITIONAL TEST AND GEOMETRY INFORMATION

[Seal fence inside diameter, $1.543 \pm 0.0005$ in. Dimensions are in inches.]

(a) 40-Tooth rotor
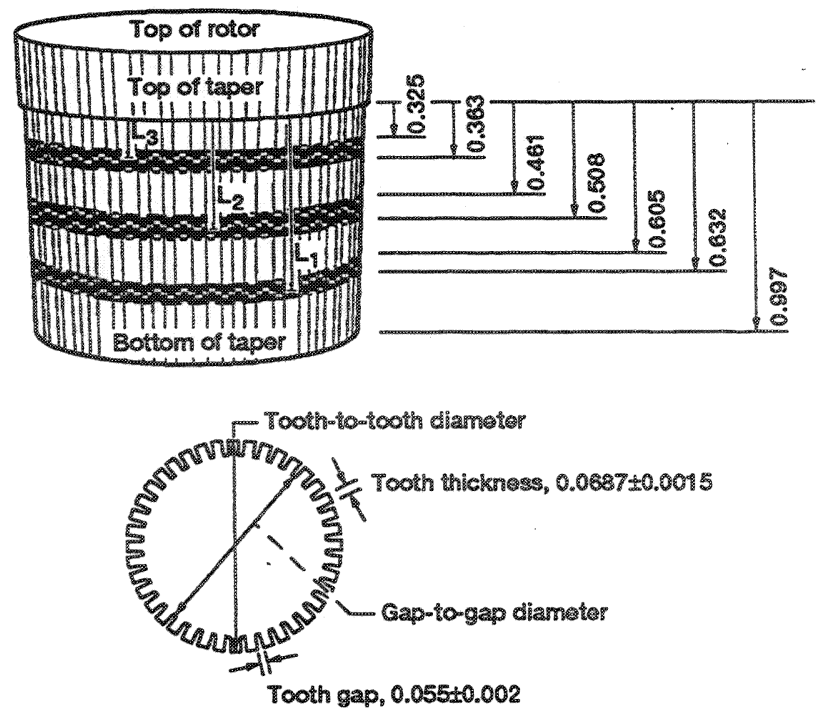

\begin{tabular}{|c|c|c|}
\hline Position & Tooth-to-tooth diameter & Gap-to-gap diamter \\
\hline Top of rotor & $1.523 \pm 0.0005$ & $1.485 \pm 0.0005$ \\
Bottom of rotor & $1.491 \pm 0.003$ & $1.483 \pm 0.003$ \\
\hline
\end{tabular}

\begin{tabular}{|c|c|c|c|}
\hline $\begin{array}{c}\text { Test } \\
\text { case }\end{array}$ & $\begin{array}{c}\text { Top-of-brush } \\
\text { wear surface }\end{array}$ & $\begin{array}{c}\text { Bottom-of-brush } \\
\text { wear surface }\end{array}$ & Average \\
\hline 1 & 0.605 & 0.632 & 0.618 \\
2 & .461 & .508 & .484 \\
3 & .325 & .303 & .344 \\
\hline
\end{tabular}

(b) Smooth rotor

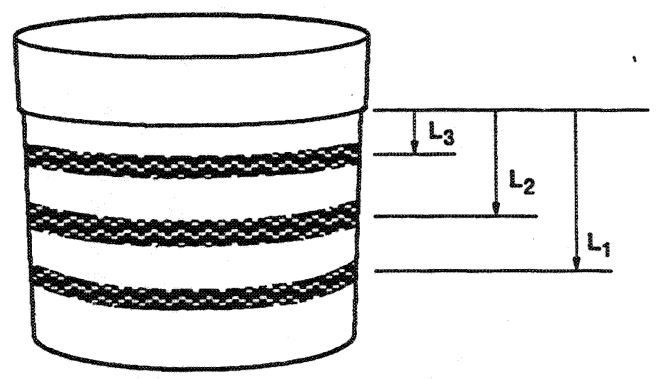

\begin{tabular}{|c|c|c|c|c|c|}
\hline $\begin{array}{l}\text { Test } \\
\text { case }\end{array}$ & $\mathbf{L}^{\mathrm{a}}$ & $\begin{array}{l}\text { Smooth-rotor } \\
\text { diameter }\end{array}$ & $\begin{array}{l}\text { Free brush } \\
\text { diameter }\end{array}$ & $\begin{array}{c}\text { Concentric } \\
\text { radial clearance }\end{array}$ & $\begin{array}{c}\text { Static } \\
\text { eccentricity }\end{array}$ \\
\hline $\begin{array}{c}\text { Before test } 1 \\
\text { After test } 1\end{array}$ & L1 & $\begin{array}{l}1.4992 \\
1.4992\end{array}$ & $\begin{array}{l}1.4932 \\
1.4958\end{array}$ & $\begin{array}{r}-0.0030 \\
-.0017\end{array}$ & $\begin{array}{l}0 \\
0\end{array}$ \\
\hline $\begin{array}{l}\text { Before test } 2 \\
\text { After test } 2\end{array}$ & L2 & $\begin{array}{l}1.5046 \\
1.5046\end{array}$ & $\begin{array}{l}1.4958 \\
1.5049\end{array}$ & $\begin{array}{c}-0.0044 \\
.0001\end{array}$ & $\begin{array}{l}0 \\
0\end{array}$ \\
\hline $\begin{array}{l}\text { Before test } 3 \\
\text { After test } 3\end{array}$ & L3 & $\begin{array}{l}1.5105 \\
1.5105\end{array}$ & $\begin{array}{l}1.5049 \\
1.5091\end{array}$ & $\begin{array}{c}-0.0028 \\
-.007\end{array}$ & $\begin{array}{r}0.013 \\
.013\end{array}$ \\
\hline
\end{tabular}

Corresponds to equivalent axial positions of 40 -tooth rotor. 
TABLE III.-PROFILOMETER RESULTS FOR 40-TOOTH ROTOR,TESTS 1, 2, AND 3

\begin{tabular}{|c|c|c|c|c|}
\hline Location & Test & $\begin{array}{c}\text { Peak groove } \\
\text { depth, } \\
\mu \mathrm{m}\end{array}$ & $\begin{array}{c}\text { Estimated } \\
\text { average depth, } \\
\mu \mathrm{m}\end{array}$ & $\begin{array}{c}\text { Wear area, } \\
\mu \mathrm{m}^{2}\end{array}$ \\
\hline Leading edge & 1 & 57 & 22 & 24910 \\
& 2 & 130 & 95 & 141680 \\
& 3 & 130 & 70 & 114370 \\
\hline Midsection & 1 & 30 & 17 & 7652 \\
& 2 & 70 & 35 & 37106 \\
& 3 & 70 & 27 & 56493 \\
\hline \multirow{2}{*}{ Trailing edge } & 1 & 25 & 12 & 6610 \\
& 2 & 65 & 35 & 48649 \\
& 3 & 67 & 30 & 56169 \\
\hline
\end{tabular}

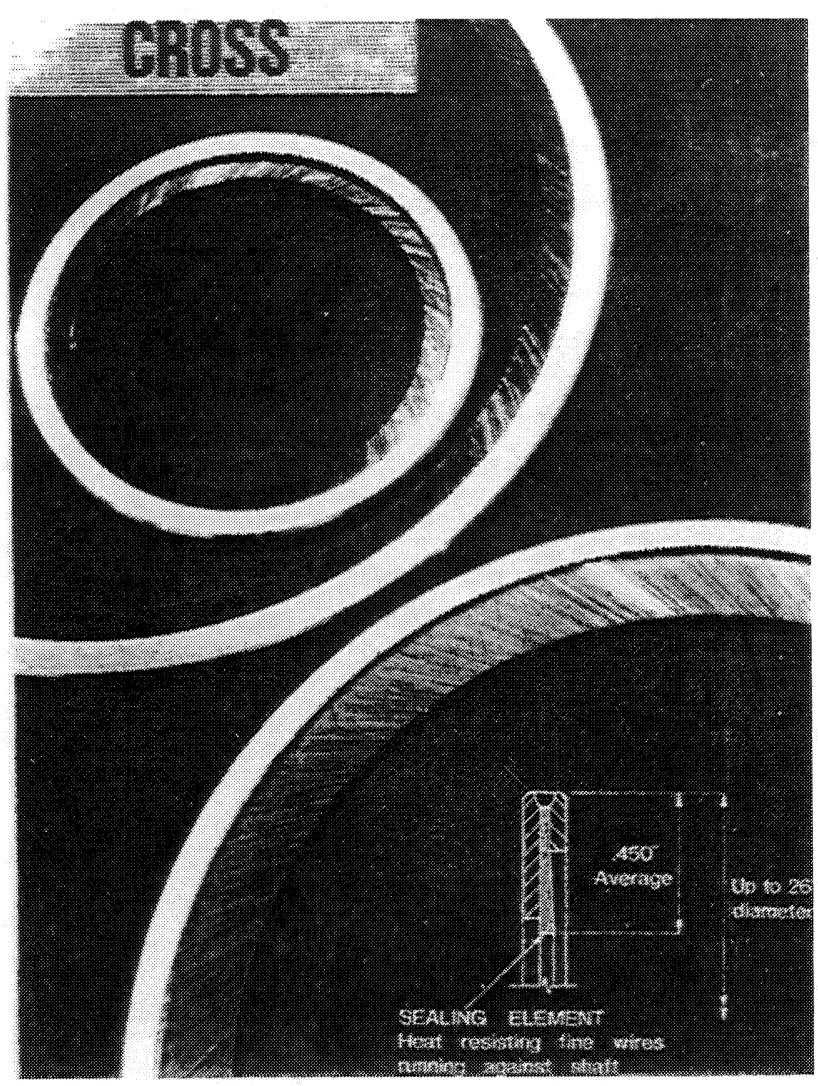

Figure 1.-Circular brush seal. (Courtesy of Cross Mfg. Ltd.)

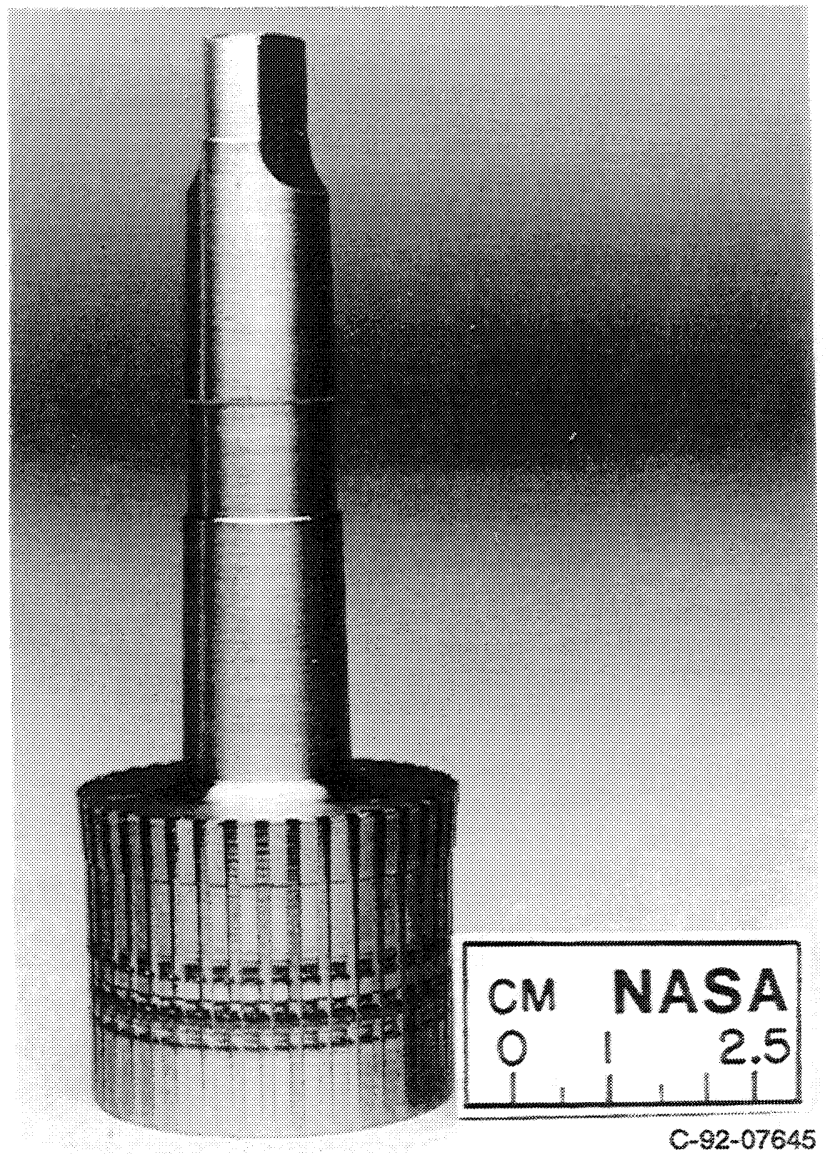

Figure 2.-Geometry of tapered, 40-tooth rotor. 


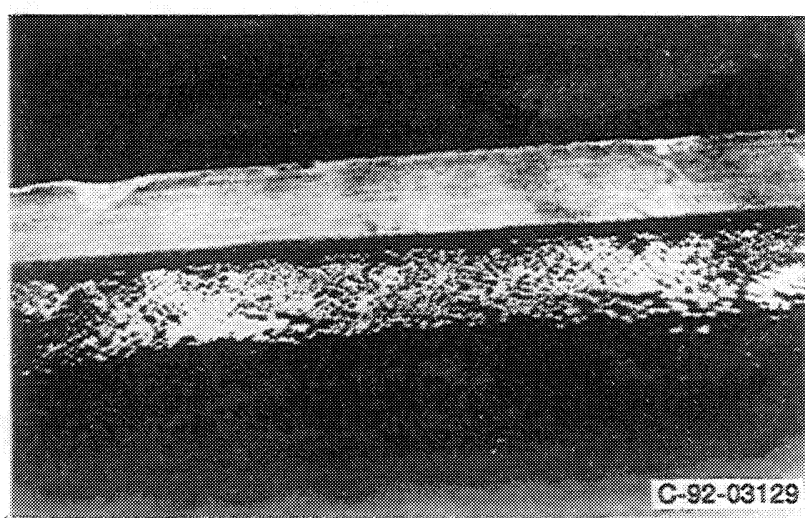

Figure 3.-Brush seal prior to tests $\left(270^{\circ}\right.$ mark).

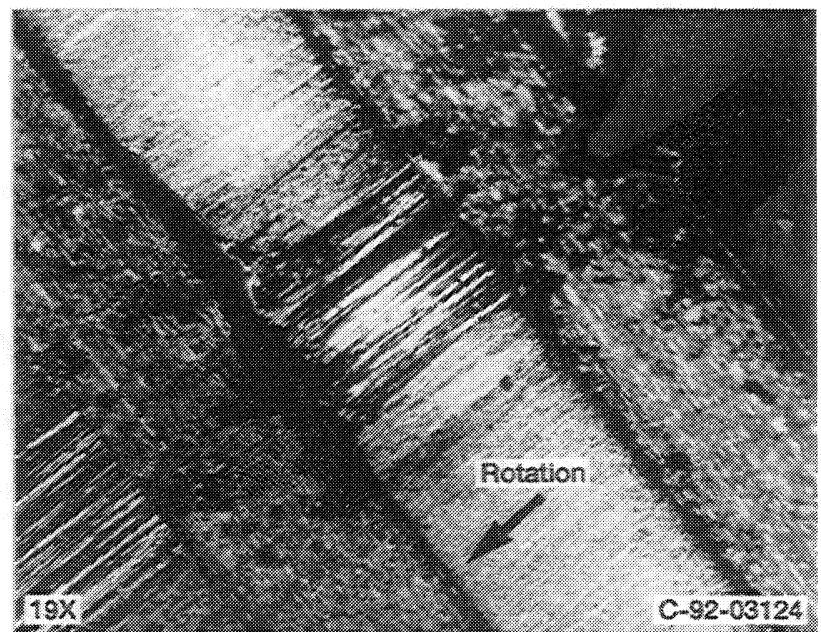

Figure 4.- Rotor surface after test 1. (Arrow shows direction of rotation.)

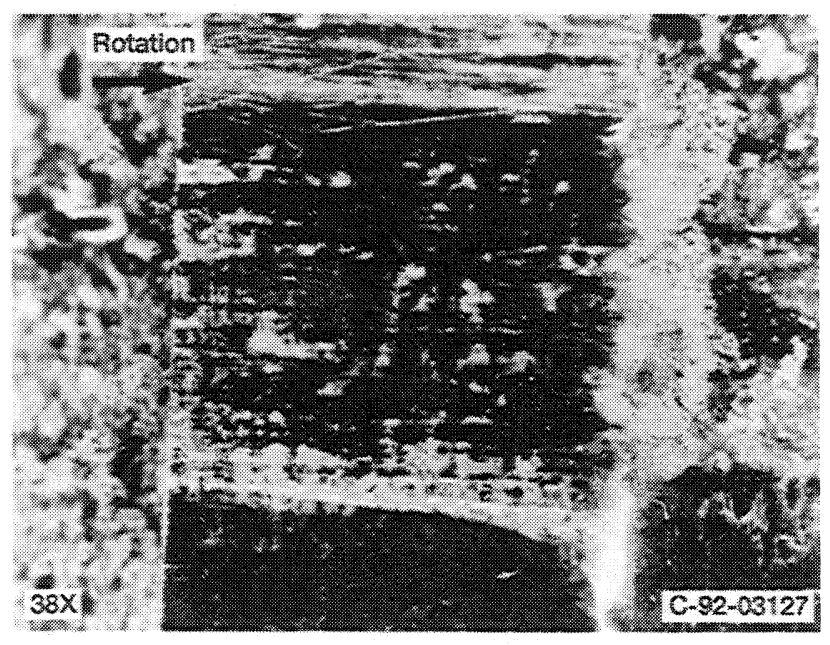

Figure 5.-Rotor land and groove after test 1. 


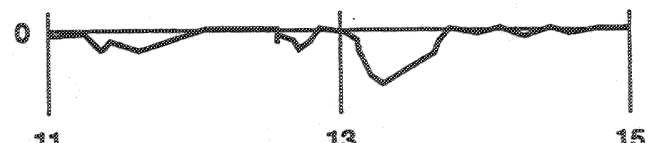

앙

13

(c) Trailing adge.

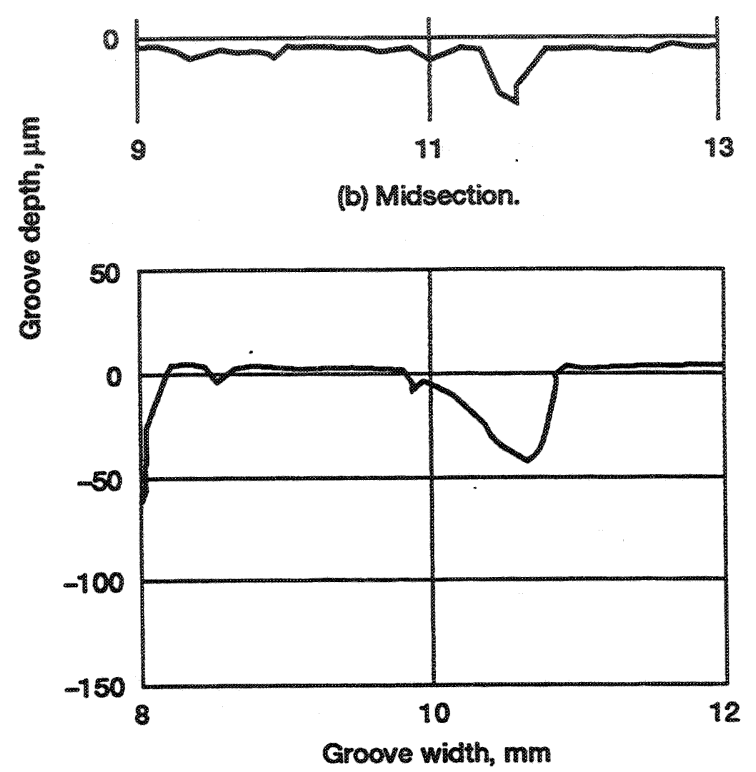

(a) Leading edge.

Figure 6. - Profilometer traces for 40-tooth rotor (test 1).

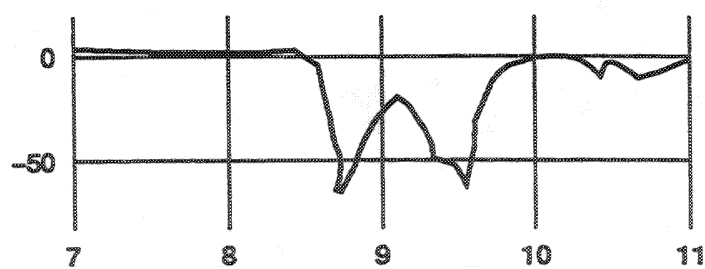

(c) Trailing solge.
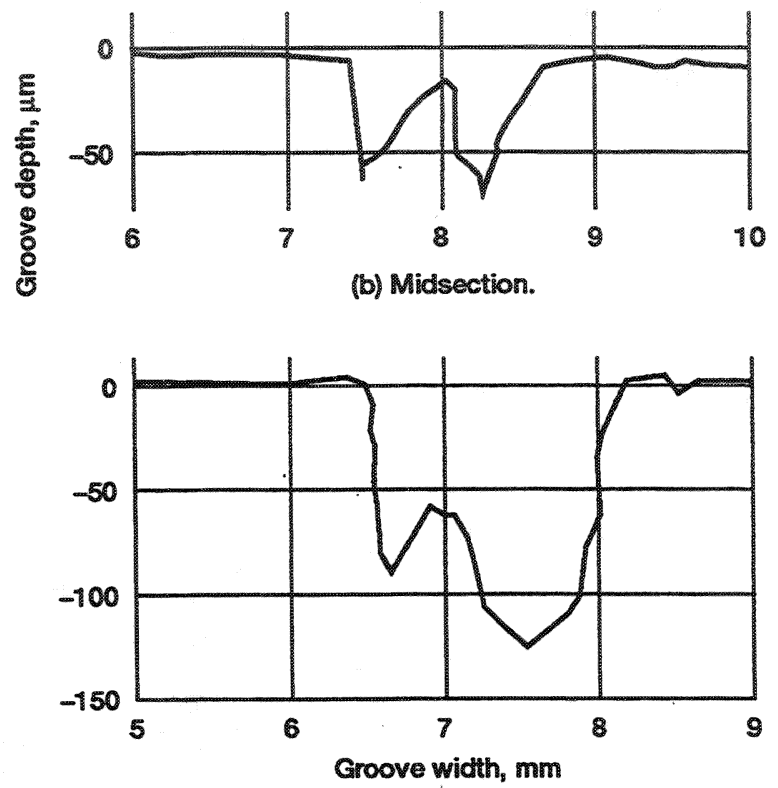

(a) Leading edge.

Figure 7.-Profilometer traces for 40-tooth rotor (test 2). 


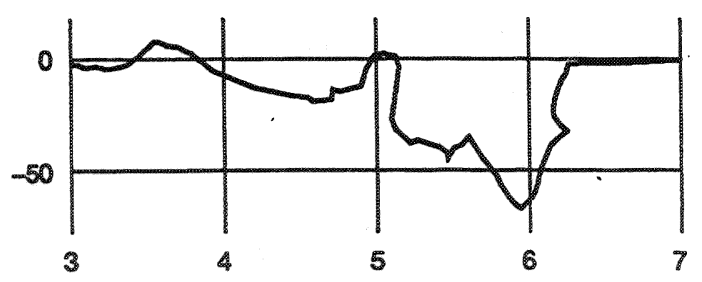

(c) Trailing edge.

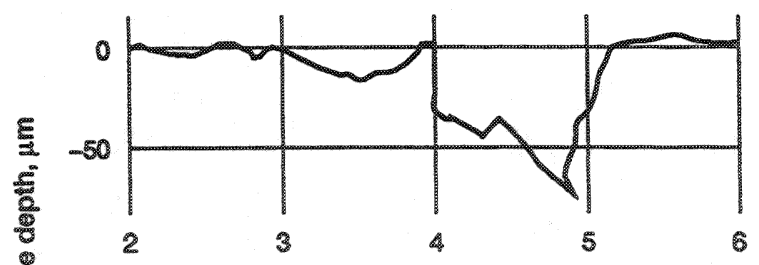

(b) Midsection.

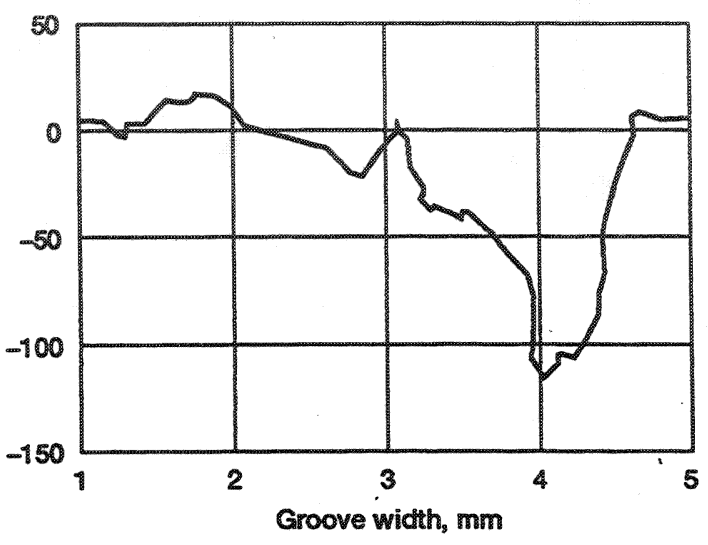

(a) Leading edge.

Figure 8.-Profilometer traces for 40-tooth rotor (test 3).

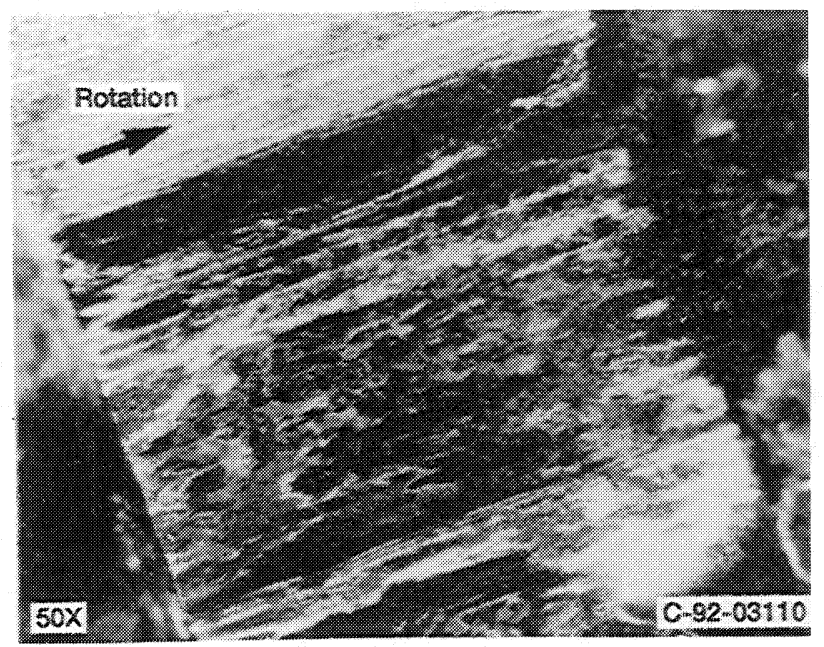

Figure 9.-Rotor land with debris and rub scars (test 2).

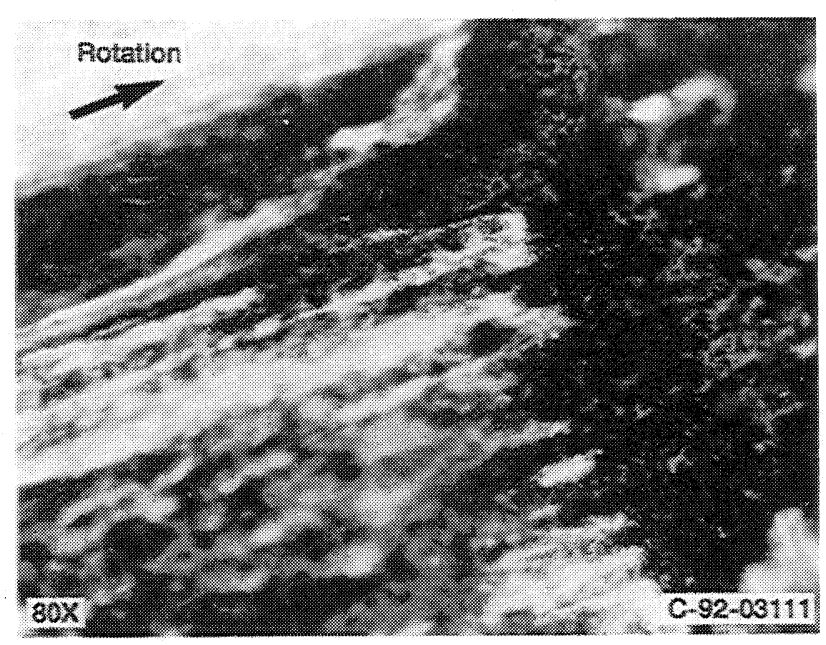

Figure 10.-Rotor leading-edge debris formation (test 2). 


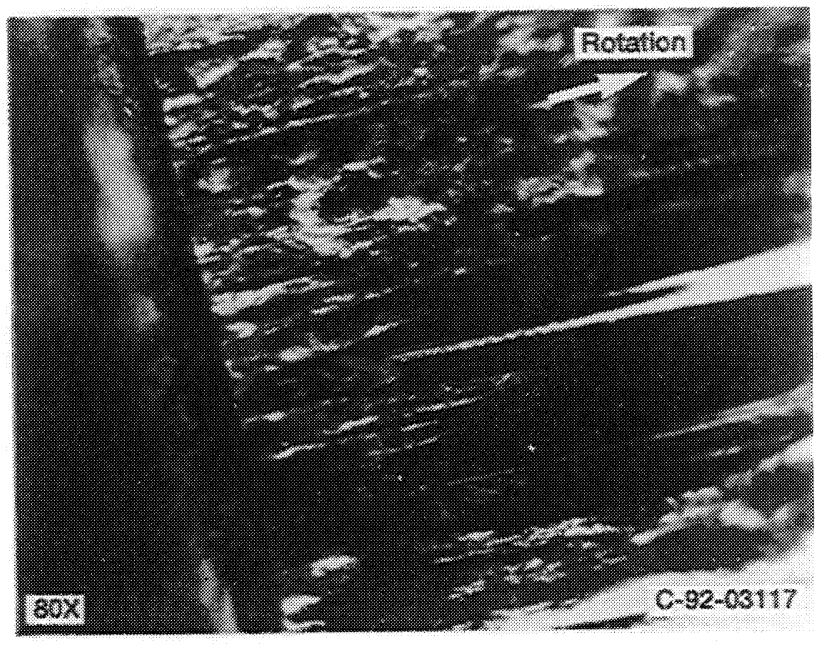

Figure 11.-Rotor tralling-edge suriace grooving and debris (test 3).

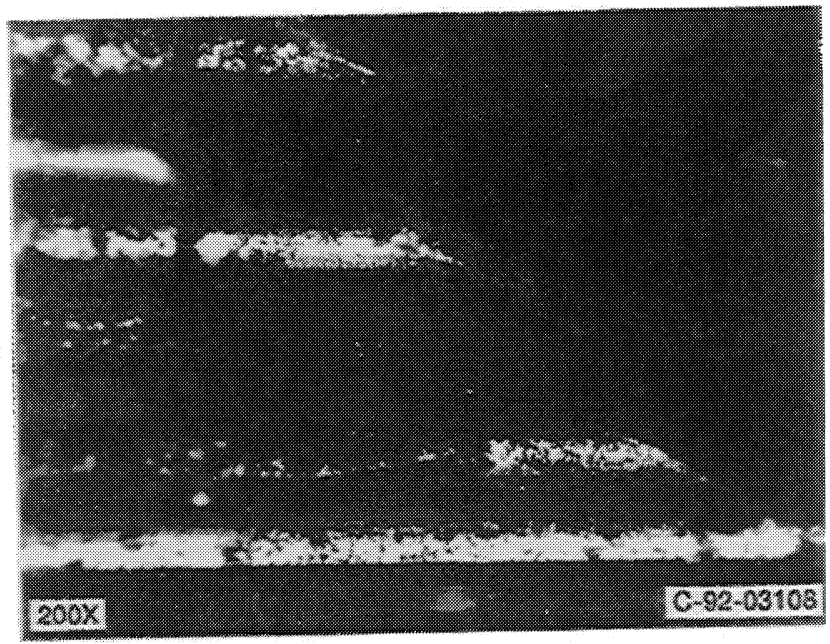

Figure 12.-Brush bristle tips with debris (test 1).

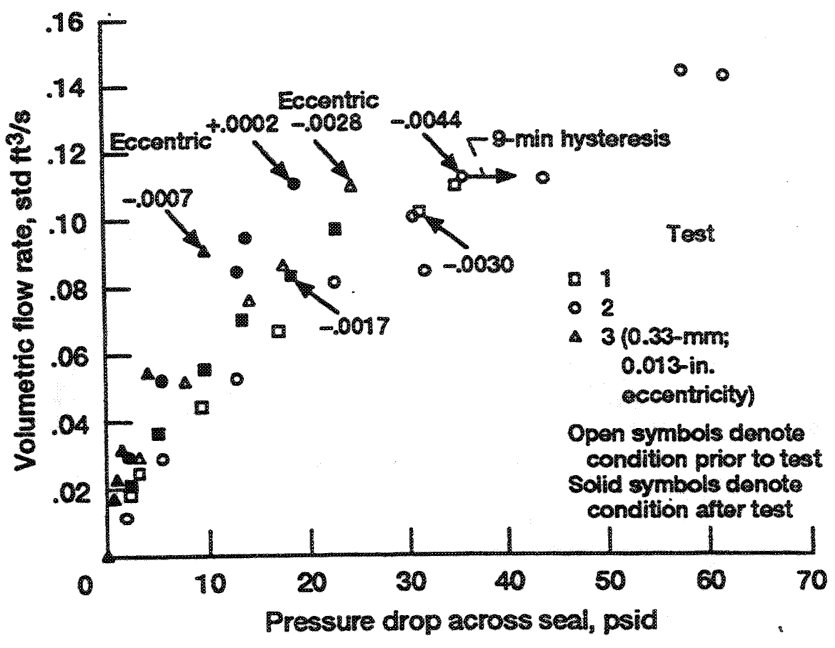

Figure 13.-Pre- and posttest leakage results for smooth rotor. 


\begin{tabular}{|c|c|c|}
\hline \multicolumn{2}{|c|}{ REPORT DOCUMENTATION PAGE } & $\begin{array}{l}\text { Form Approved } \\
\text { OMB No. 0704-0188 }\end{array}$ \\
\hline \multicolumn{3}{|c|}{$\begin{array}{l}\text { Public reporting burden for this collection of information is estimated to average } 1 \text { hour per response, including the time for reviewing instructions, searching existing data sources, } \\
\text { gathering and maintaining the data needed, and completing and reviewing the collection of information. Send comments regarding this burden estimate or any other aspect of this } \\
\text { collection of information, including suggestions for reducing this burden, to Washington Headquarters Services, Directorate for Information Operations and Reports, } 1215 \text { Jefferson } \\
\text { Davis Highway, Suite 1204, Arlington, VA 22202-4302, and to the Office of Management and Budget, Paperwork Reduction Project (0704-0188), Washington, DC 20503. }\end{array}$} \\
\hline 1. AGENCY USE ONLY (Leave blank) & $\begin{array}{r}\text { 2. REPORT DATE } \\
\text { June } 1993\end{array}$ & $\begin{array}{l}\text { ND DATES COVERED } \\
\text { echnical Memorandum }\end{array}$ \\
\hline $\begin{array}{l}\text { 4. TITLE AND SUBTITLE } \\
\text { Brush Seal Low Surface Spe }\end{array}$ & Brush Seal Low Surface Speed Hard-Rub Characteristics & 5. FUNDING NUMBERS \\
\hline $\begin{array}{l}\text { 6. AUTHOR(S) } \\
\text { Robert C. Hendricks, Julie A }\end{array}$ & arlile, and Anita D. Liang & WU-584-03-11 \\
\hline $\begin{array}{l}\text { 9. SPONSORING/MONITORING AGEI } \\
\text { National Aeronautics and } \mathrm{Sp} \\
\text { Washington, DC } 20546-00\end{array}$ & $\begin{array}{l}\text { NAME(S) AND ADDRESS(ES) } \\
\text { Administration }\end{array}$ & $\begin{array}{l}\text { 10. SPONSORING/MONITORING } \\
\text { AGENCY REPORT NUMBER } \\
\text { NASA TM-106169 } \\
\text { AIAA-93-2534 }\end{array}$ \\
\hline
\end{tabular}

Prepared for the 29th Joint Propulsion Conference and Exhibit sponsored by the AIAA, SAE, ASME, and ASEE, Monterey, California, June 28-30, 1993. Responsible person, Robert C. Hendricks, 216-433-7507.

\begin{tabular}{|l|l|l|l|l}
\hline 12a. DISTRIBUTION/AVAILABILITY STATEMENT & 12b. DISTRIBUTION CODE
\end{tabular}

Unclassified - Unlimited

Subject Category: 34

Available electronically at http://gltrs.grc.nasa.gov

This publication is available from the NASA Center for AeroSpace Information, 301-621-0390.

13. ABSTRACT (Maximum 200 words)

The bristles of a 38.1-mm (1.5-in.) diameter brush seal were flexed by a tapered, 40-tooth rotor operating at $2600 \mathrm{rpm}$ that provided sharp leading-edge impact of the bristles with hard rubbing of the rotor lands. Three separate tests were run with the same brush accumulating over $1.3 \times 10^{9}$ flexure cycles while deteriorating $0.2 \mathrm{~mm}(0.008 \mathrm{in}$.) radially. In each, the test bristle incursion depth varied from 0.130 to $0.025 \mathrm{~mm}(0.005$ to $0.001 \mathrm{in}$.) or less (start to stop), and in the third test the rotor was set $0.25 \mathrm{~mm}(0.010 \mathrm{in}$.) eccentric. Runout varied from 0.025 to $0.076 \mathrm{~mm}(0.001$ to 0.003 in.) radially. The bristles wore but did not pull out, fracture, or fragment. Bristle and rotor wear debris were deposited as very fine, nearly amorphous, highly porous materials at the rotor groove leading edges and within the rotor grooves. The land leading edges showed irregular wear and the beginning of a convergent groove that exhibited sharp, detailed wear at the land trailing edges. Surface grooving, burnishing, "whipping," and hot spots and streaks were found. With a smooth-plug rotor post-test leakage increased 30 percent over pretest leakage.

\begin{tabular}{|c|c|c|c|}
\hline 14. SUBJECT TERMS & & Seals; Brush; Rub; Tribology & $\begin{array}{c}\text { 15. NUMBER OF PAGES } \\
14 \\
\end{array}$ \\
\hline NSN 7540-01-280-5500 & & & $\begin{array}{l}\text { andard Form } 298 \text { (Rev. 2-89) } \\
\text { scribed by ANSI Std. Z39-18 } \\
3-102\end{array}$ \\
\hline
\end{tabular}

